\title{
Noncasein nitrogen analysis of ultrafiltration and microfiltration retentate
}

\author{
H. Zhang ${ }^{\star}$ and L. E. Metzgert ${ }^{1}$ \\ *Department of Dairy Science, and \\ †Midwest Dairy Foods Research Center, South Dakota State University, Brookings 57006
}

\begin{abstract}
Previous research has suggested that the standard noncasein nitrogen (NCN) measurement method for milk overestimates the NCN content of microfiltration (MF) retentate. The objective of this study was to develop a modified method to more accurately measure the NCN content of ultrafiltration and MF retentate products. The standard method is based on precipitation of casein micelles at their isoelectric point (4.6) with acetic acid. In the standard method, a 10-mL milk sample and $75 \mathrm{~mL}$ of $38^{\circ} \mathrm{C}$ water are placed in a 100$\mathrm{mL}$ volumetric flask. One milliliter of $10 \%$ acetic acid solution is added and the flask is incubated at $38^{\circ} \mathrm{C}$ for $10 \mathrm{~min}$. Subsequently, $1 \mathrm{~mL}$ of $1 N$ sodium acetate solution is added and mixed. After cooling the contents to $20^{\circ} \mathrm{C}$, the flask is made up to $100 \mathrm{~mL}$ with water, mixed, and then filtered (Whatman No. 1 filter paper). The $\mathrm{N}$ content of the filtrate is then determined by Kjeldahl analysis and referred to as NCN. A method was developed that used a 50-mL centrifugal tube instead of a volumetric flask. This modification facilitated measurement of the $\mathrm{pH}$ after addition of acetic acid. Subsequently, the sample was centrifuged $(800 \times g$ at $25^{\circ} \mathrm{C}$ ) for $10 \mathrm{~min}$ to facilitate filtration with a smaller pore size filter paper (Whatman no. 6). In this study, we evaluated the effect of $\mathrm{pH}$ after addition of $1 \%$ acetic acid and $\mathrm{pH}$ of the final filtrate on NCN analysis. Four $\mathrm{pH}$ levels after acetic acid addition (4.0, 4.2, 4.4, and 4.6) and $2 \mathrm{pH}$ levels after sodium acetate addition (4.6 and 4.8) were evaluated. As the $\mathrm{pH}$ after acetic acid addition was increased from 4.0 to 4.6 , the NCN content significantly decreased. Sodium dodecyl sulfate PAGE results also indicated that the casein fractions present in the filtrate were significantly decreased when the $\mathrm{pH}$ was increased from 4.0 to 4.6. The NCN content slightly decreased but the difference was not significant when the final $\mathrm{pH}$ of the filtrate was increased from 4.6 to 4.8. Subsequently, the NCN contents of several ultrafiltration and MF samples were determined using the
\end{abstract}

Received August 6, 2010.

Accepted January 5, 2011.

${ }^{1}$ Corresponding author: Lloyd.Metzger@sdstate.edu standard method and modified method. The modified method gave significantly lower NCN values for most samples as compared with the standard method.

Key words: noncasein nitrogen, ultrafiltration retentate, microfiltration retentate, $\mathrm{pH}$

\section{INTRODUCTION}

Bovine milk protein consists of caseins, a group of proteins that precipitate upon acidification to $\mathrm{pH} 4.6$, and whey proteins that remain in solution at $\mathrm{pH} 4.6$ (Walstra and Jenness, 1984). Caseins include 4 kinds of polypeptide chains $\left(\alpha_{\mathrm{s}^{-}}, \alpha_{\mathrm{s} 2^{-}}, \beta-\right.$, and $\kappa$-caseins $)$ and some derivatives formed by proteolysis of these chains, including $\gamma$-caseins, which are the $\mathrm{C}$-terminal segments formed by cleavage of $\beta$-casein by the enzyme plasmin (Fox and Brodkorb, 2008). The corresponding N-terminal fragments appear in the whey during cheese making and have long been designated as proteose peptones. Whey protein consists of $\alpha$-lactoalbumin, $\beta$-lactoglobulin, bovine serum albumin, immunoglobulins, and small molecular weight peptides from proteolysis of caseins.

Caseins tend to self-associate into polymers (von Hippel and Waugh, 1955; Walstra and Jenness, 1984). Almost all caseins in fresh milk exist as large colloidal particles in spherical micelles (Walstra and Jenness, 1984). Currently, physical chemists use the term micelle to describe aggregates of amphipathic molecules (Fox and Brodkorb, 2008). McMahon and Oommen (2008) suggested 5 possible interactions that may be involved in casein polymerization (aggregation): calcium interactions with phosphoserine groups, hydrophobic and hydrophilic interactions, hydrogen bonding, and electrostatic interaction such as calcium bridging between negatively charged sites.

It is well recognized that the solubility of proteins depends to a great extent on the $\mathrm{pH}$ and the concentration of salts in the system (Jenness and Patton, 1959). Proteins demonstrate a minimum solubility at their isoelectric point (pI) in the absence of salts. Neutral salts at low concentration increase the charges on proteins and, thus, increase their solubility, which is known as salting-in. Under high concentrations, salt ions com- 
pete with the protein for water molecules and cause a decrease in solubility. This phenomenon of so-called salting-out is widely used as a means of fractionating protein mixtures by precipitation. Walstra and Jenness (1984) indicated that like most protein, casein can be salted out or precipitated by $\mathrm{Ca}^{2+}$.

Various procedures are used to separate milk proteins into fractions or individual components that can then be analyzed separately (Shahani and Sommer, 1951; Aschaffenburg and Drewry, 1958; Farah, 1979). Classical fractions (Walstra and Jenness, 1984; Barbano et al., 1991; Lynch and Barbano, 1998) involve precipitation of casein at $\mathrm{pH} 4.6$ and precipitation of all proteins with trichloroacetic acid at a final concentration of $12 \%$ (wt/vol). To avoid the necessity for washing the precipitate quantitatively, $\mathrm{N}$ is determined in the filtrate. The principle of determining noncasein nitrogen $(\mathbf{N C N})$ content is that casein is precipitated from milk at $\mathrm{pH} 4.6$ (Moir, 1931; Rowland, 1938). The standard method (AOAC, 2000; Hooi et al., 2004) uses acetic acid for $\mathrm{pH}$ adjustment and sodium acetate as a buffer. The precipitated casein is then removed by filtration. The filtrate is assumed to contain only NCN components of milk.

Nelson and Barbano (2005) used the standard method (AOAC 2000; 33.2.64, 998.05) to determine the NCN content of microfiltration (MF) retentate samples. Their research adjusted sample size to account for the higher protein content of retentate. Based on electrophoresis analysis they concluded that the standard method overestimates the NCN content of microfiltration retentate. Previous publications related to the standard method indicated that particulate matter can occasionally be found in the filtrate (Lynch et al., 1998; AOAC, 2000; Hooi et al., 2004). In these instances, the sample preparation should be repeated to ensure that the filtrate is clear. However, no recommendations for modification of the method have been suggested. We speculate that with MF and UF samples, the casein is not completely coagulated and separated from the filtrate during sample preparation, which may cause an overestimation of the NCN content.

In preliminary research, we evaluated the effect of $\mathrm{CaCl}_{2}$ and $\mathrm{NaCl}$ addition on the performance of $\mathrm{NCN}$ analysis of MF retentate and skim milk. In this preliminary study, we concluded that $\mathrm{CaCl}_{2}$, at high concentration $(0.89 \%)$, with or without $\mathrm{NaCl}$, increased NCN contents as compared with the standard method, whereas no difference in NCN was observed between a low-concentration $\mathrm{CaCl}_{2}$ solution $(0.022 \%)$ and the standard method. The calcium-induced solubilization of caseins at high concentration was also found by other researchers (Farrell Jr. and Kumosinski, 1988; MoraGutierrez et al., 1993; Philippe et al., 2003), although their conditions were different from those in the current study. Consequently, the addition of $\mathrm{CaCl}_{2}$ or $\mathrm{NaCl}$ to the precipitation solvent will not improve the accuracy of NCN analysis.

Additionally, we determined that with the standard method, addition of $1 \mathrm{~mL}$ of $10 \%$ acetic acid was subject to analyst error, and addition of $10 \mathrm{~mL}$ of $1 \%$ acetic acid was preferred. Other issues observed with the standard method included the use of a $100-\mathrm{mL}$ volumetric flask, which prevented measurement of the $\mathrm{pH}$ after acetic acid addition, as well as issues with slow or incomplete filtration. Based on these observations, we proposed several modifications to the standard method. To address $\mathrm{pH}$ measurement and filtration issues encountered in the standard method, we proposed using a $50-\mathrm{mL}$ centrifuge tube to replace the $100-\mathrm{mL}$ volumetric flask in the standard method. The use of a $50-\mathrm{mL}$ centrifuge tube facilitates the determination of the $\mathrm{pH}$ after addition of acetic acid. The measurement of the $\mathrm{pH}$ after acetic acid addition is critical when samples with a range in total protein content are analyzed, because the level of total protein will affect the amount of acetic acid required to reach $\mathrm{pH}$ 4.6. It is also important to adjust the sample weights of MF and UF retentate samples to account for their increased total protein content relative to milk. We also recommend that sample size be determined by weight instead of volume. To facilitate filtration of the flocculated caseins, we proposed use of centrifugation $\left(800 \times g\right.$ at $\left.25^{\circ} \mathrm{C}\right)$ for $10 \mathrm{~min}$ and use of a smaller pore size filter paper (Whatman No. 6/42) to replace the larger pore size filter paper (Whatman No. $1 / 40)$ used in the standard method.

The objective of this study was to determine the effect of $\mathrm{pH}$ after acetic acid addition and final filtrate $\mathrm{pH}$ on NCN analysis using the modified method. Using our modified method, we also compared the optimized modified method to the standard method for evaluation of MF and UF retentate samples.

\section{MATERIALS AND METHODS}

\section{Experimental Design and Statistical Analysis}

Effect of $p H$ on the Modified NCN Method. An MF retentate sample (10.06\% protein) made from skim milk was analyzed for NCN content using $4 \mathrm{pH}$ levels $(4.0,4.2,4.4$, and 4.6) after acetic acid addition and 2 $\mathrm{pH}$ levels (4.6 and 4.8) after sodium acetate addition. Each $\mathrm{pH}$ combination was performed in triplicate. A randomized complete block design with a factorial arrangement was used, and the total experimental units was $24(4 \mathrm{pH}$ values after addition of acetic acid $\times 2$ $\mathrm{pH}$ values of final filtrate $\times 3$ replicates). The retentate sample was also analyzed using the standard NCN 
Table 1. The amount of acetic acid and sodium acetate added to adjust $\mathrm{pH}$ values and the effect of $\mathrm{pH}$ on the noncasein nitrogen (NCN) protein content of microfiltration retentate $(\mathrm{n}=3)$

\begin{tabular}{|c|c|c|c|c|c|c|}
\hline Treatment & \multicolumn{3}{|c|}{$1 \%$ Acetic acid addition } & \multicolumn{2}{|c|}{$1 N$ Sodium acetate addition } & $\begin{array}{c}\mathrm{NCN} \\
(\%, \mathrm{n}=3)\end{array}$ \\
\hline $\mathrm{pH} 4.0-4.8$ & 1.63 & 7.00 & $4.02 \pm 0.01$ & 1.15 & $4.80 \pm 0.01$ & $1.27 \pm 0.01^{\mathrm{a}}$ \\
\hline $\mathrm{pH} 4.2-4.6$ & 1.63 & 5.00 & $4.21 \pm 0.01$ & 0.32 & $4.63 \pm 0.00$ & $1.26 \pm 0.01^{\mathrm{ab}}$ \\
\hline $\mathrm{pH} 4.2-4.8$ & 1.63 & 5.00 & $4.21 \pm 0.02$ & 0.53 & $4.77 \pm 0.01$ & $1.23 \pm 0.02^{\mathrm{ab}}$ \\
\hline $\mathrm{pH} 4.6-4.6$ & 1.63 & 2.85 & $4.57 \pm 0.01$ & 0.00 & $4.67 \pm 0.09$ & $1.12 \pm 0.02^{\mathrm{c}}$ \\
\hline $\mathrm{pH} 4.6-4.8$ & 1.63 & 2.85 & $4.55 \pm 0.01$ & 0.10 & $4.83 \pm 0.01$ & $1.11 \pm 0.01^{\mathrm{c}}$ \\
\hline Standard method ${ }^{1}$ & 3.25 & 10 & Not measured & 1.00 & $4.70 \pm 0.02$ & $1.26 \pm 0.02^{\mathrm{a}}$ \\
\hline
\end{tabular}

${ }^{\mathrm{a}-\mathrm{c}}$ Different letters within the same column indicate significant difference among treatment means $(P<0.05)$. Values are means \pm standard error.

${ }^{1}$ Sample preparation using the standard method followed the procedures of Hooi et al. (2004), except that a sample size of $3.25 \mathrm{~g}$ of retentate and $10 \mathrm{~mL}$ of $1 \%$ acetic acid were used.

method to serve as a control. Additionally, SDS-PAGE was conducted to determine the protein fractions present in filtrates from the lowest and highest $\mathrm{pH}$ levels after acetic acid addition (4.0 and 4.6) and $2 \mathrm{pH}$ levels after sodium acetate addition (4.6 and 4.8). The filtrate obtained from the standard method was also analyzed. A raw skim milk sample was analyzed on each gel to identify the various proteins present in bovine milk. Each treatment was performed in duplicate for the gel electrophoresis. Each protein fraction relative to the total protein in the filtrate was analyzed and the detailed electrophoresis procedure is described in the following section. Analysis of variance was completed in the general linear model and a Bonferroni multiple comparison was used with a significance level of 0.05 to compare all treatment means (SPSS 16.0, SPSS Inc., Chicago, IL).

Verification of the Modified NCN Method. Six retentate samples from MF of skim milk (total protein concentrations of $6.9,8.6,10.4,11.2,12.4$, and $15.5 \%$ ) and also 6 retentate samples from UF of skim milk (total protein concentrations at $5.0 \%, 6.0 \%, 8.0 \%, 10.0 \%$, and $14.4 \%$ ) were used for evaluation. In addition, a retentate sample that was produced with a combination of MF and UF of skim milk ( $15.1 \%$ total protein) was included in the study. Each retentate sample was analyzed in triplicate for NCN protein content using the standard method and the modified method. A one-tailed/direction paired design was used to compare the standard method and modified method. A significance level of 0.05 was used to compare the mean differences.

\section{NCN Analysis}

Effect of $p H$ on the Modified NCN Method. Sample preparation using the standard method fol- lowed the procedures of Hooi et al. (2004), except that a sample size of $3.25 \mathrm{~g}$ of retentate and $10 \mathrm{~mL}$ of $1 \%$ acetic acid were used. The sample preparation using the modified procedure used a 50-mL centrifuge tube and half of the sample weight $(1.63 \mathrm{~g})$.

In the modified procedure, the weight of the $50-\mathrm{mL}$ centrifuge tube was determined and approximately $1.63 \mathrm{~g}$ of retentate was added. Subsequently, $37.5 \mathrm{~mL}$ of water and the required amount of $1 \%$ acetic acid was added to obtain the desired $\mathrm{pH}$ values $(4.0,4.2,4.4$, and 4.6). The centrifuge tube was then mixed and incubated for $10 \mathrm{~min}$ at $38^{\circ} \mathrm{C}$. After incubation, $1 N$ sodium acetate was added to obtain the desired $\mathrm{pH}$ (4.6 and 4.8). The weight of the contents of the tube was then adjusted to $50 \mathrm{~g}$ using distilled water. The tube was centrifuged at $800 \times g$ for $10 \mathrm{~min}$ at $25^{\circ} \mathrm{C}$, and filtered using Whatman No. 6 filter paper. The amount of $1 \%$ acetic acid and $1 N$ sodium acetate required to achieve the targeted $\mathrm{pH}$ values is shown in Table 1.

Verification of the Modified NCN Method. The procedures for the modified method and standard method were as described in the previous section. The adjusted sample weight, volumes of $1 \%$ acetic acid and $1 \mathrm{~N}$ sodium acetate used to obtain the desired $\mathrm{pH}$ values, as well as the actual $\mathrm{pH}$ values obtained for each sample, are all presented in Table 2. Ten milliliters of $1 \%$ acetic acid solution and $1 \mathrm{~mL}$ of $1 N$ sodium acetate solution were used for all of the samples in the standard method.

The weight of the retentate sample was adjusted to be equivalent to $3.25 \%$ total protein in $10 \mathrm{~mL}$ of bovine milk. The sample weight for the standard method in the $100-\mathrm{mL}$ volumetric flask was calculated according to the equation: $\mathrm{X}=(10 \times 3.25) / \mathrm{Y}$. The modified method used a $50-\mathrm{mL}$ centrifuge tube, and the weight of each 
Table 2. The adjusted sample weight and $1 \%$ acetic acid and $1 \mathrm{~N}$ sodium acetate addition to reach the targeted $\mathrm{pH}$ values

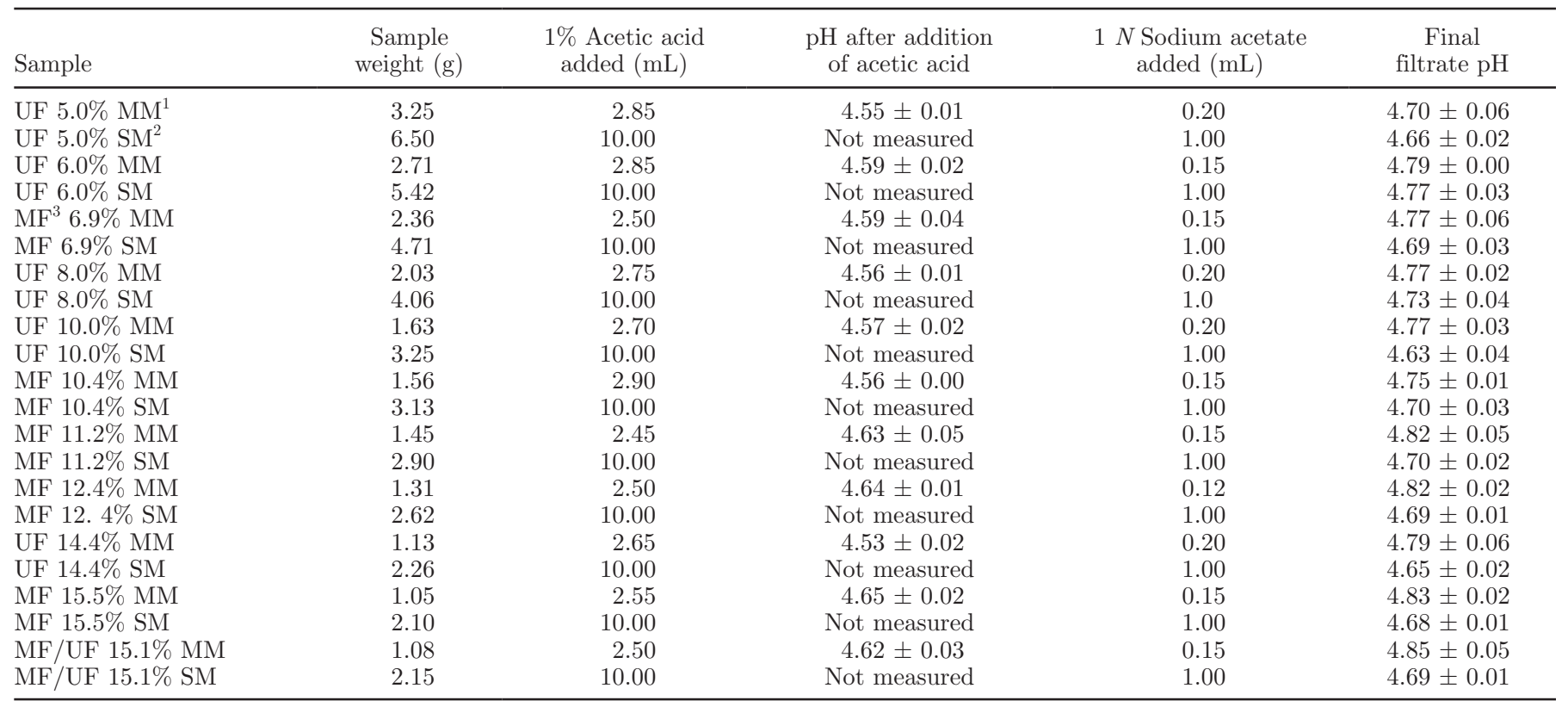

${ }^{1}$ Modified method. The modified method used a 50-mL centrifuge tube, and the weight of each sample was correspondingly half of the sample size used in the standard method.

${ }^{2}$ Standard method (AOAC, 2000; Hooi et al., 2004). Sample preparation using the standard method followed the procedures of Hooi et al. (2004), except that a sample size of $3.25 \mathrm{~g}$ of retentate and $10 \mathrm{~mL}$ of $1 \%$ acetic acid were used.

${ }^{3}$ Microfiltration.

sample was correspondingly half of its sample size using the standard method to account for the difference. The $\mathrm{X}$ term represents the sample size in grams, 10 represents the $10-\mathrm{mL}$ sample size of bovine milk (its density is close to 1.0) used in the standard method, 3.25 represents the total protein percentage of a typical bovine milk, and Y represents the total protein content of the retentate sample. For example, the sample size of the retentate with $10 \%$ total protein was calculated as 3.25 $\mathrm{g}$; the corresponding sample weight for the modified method was $1.63 \mathrm{~g}$. The weights of all of the samples for both methods in the study were adjusted according to the described principles.

\section{Polyacrylamide Gel Electrophoresis}

The PhastSystem Electrophoresis apparatus (Pharmacia LKB Biotechnology, Piscataway, NJ) was used to conduct SDS-PAGE in this study. Sample buffer containing $10 \mathrm{mM}$ Tris-HCl buffer, $\mathrm{pH} 6.8,1.0 \%$ (wt/ vol) SDS, $20 \%$ (vol/vol) glycerol, and $0.02 \%$ (wt/vol) bromophenol was used. Just before use, $1 \mathrm{~mL}$ of 2 -mercaptoethanol was added to $19 \mathrm{~mL}$ of the sample buffer. Prior to electrophoresis analysis, the NCN filtrate was adjusted to $\mathrm{pH} 6.8$ with $\mathrm{NaOH}$ solutions $(5 \mathrm{~N}$ and $1 \mathrm{~N}$ ). Then, $0.5 \mathrm{~mL}$ of the $\mathrm{pH}$-adjusted NCN filtrate was mixed with $0.5 \mathrm{~mL}$ of buffer solution containing 2-mercaptoethanol, and heated at $100^{\circ} \mathrm{C}$ for $5 \mathrm{~min}$. The gel was a PhastGel Gradient 8-25 (Pharmacia LKB Biotechnology), and the separation was conducted at $250 \mathrm{~V}, 3.0 \mathrm{~W}$, and $15^{\circ} \mathrm{C}$ for $75 \mathrm{~V}$ hours (approximately $25 \mathrm{~min})$. The gel was stained with a $0.23 \%$ solution of Coomassie Blue R-350 (Pharmacia LKB Biotechnology) and de-stained in a methanol (5\%) and acetic acid (7\%) solution. Destained gels were scanned using an HP Scanjet (7650; Hewlett-Packard, Houston, TX). ImageQuant TL image analysis software (version 7.0; Amersham Biosciences, Piscataway, NJ) was used to quantify the intensity of each protein fraction relative to the total protein intensity within each lane. Manual adjustment of lanes, rolling ball background subtraction, and adjusted band detection were used to maximize the accuracy of the analysis. The intensity of all casein fractions relative to the total intensity of all bands in each lane (sample) was also determined.

\section{RESULTS AND DISCUSSION}

\section{Effect of $\mathrm{pH}$ on the Modified NCN Method}

Table 1 shows the NCN content obtained with the various treatments. When the $\mathrm{pH}$ after acetic acid addition was increased from 4.0 to 4.6 , the $\mathrm{NCN}$ content decreased. The NCN content of the $\mathrm{pH} 4.4$ and 4.6 
treatments (after acetic acid addition) was significantly $(P<0.05)$ lower than the NCN obtained with the standard method. The obvious reason for this difference was that casein micelles precipitate more completely at their pI (4.6). The initial method development studies (Moir, 1931; Rowland, 1938) that led to the current standard method also confirmed that the excess addition of acetic acid decreased the amount of casein recovered. Rowland (1938) pointed out that the addition of excess acid would disperse some casein as casein acetate, and it was unlikely that the subsequent addition of sodium acetate to increase the $\mathrm{pH}$ would result in conversion of soluble casein acetate into insoluble casein.

The standard method is based on precipitation of caseins at the pI of 4.6 with acetic acid. However, the standard method does not monitor the $\mathrm{pH}$ after acetic acid addition. This situation occurs because the use of a $100-\mathrm{mL}$ volumetric flask makes it difficult to measure the $\mathrm{pH}$ after acetic acid addition. In the modified method we used a $50-\mathrm{mL}$ centrifuge tube to facilitate $\mathrm{pH}$ measurement after acetic acid addition. Table 1 shows that using approximately one-quarter of the amount of $1 \%$ acetic acid required in the standard method (10 $\mathrm{mL}$ ), the modified method obtained a $\mathrm{pH}$ value of 4.6 after acetic acid addition, even though the sample size was one-half of that of the standard method. Thus, we can reasonably infer that the acetic acid quantity $(10 \mathrm{~mL})$ used in the standard method results in a $\mathrm{pH}$ value lower than 4.6. Consequently, we believe that incomplete precipitation of casein from excess acid addition occurs in the standard method and contributes to the overestimation of the NCN content of retentate samples. These results indicate that the practice of adjusting sample size relative to the protein content of the retentate samples will result in a $\mathrm{pH}$ value less than $\mathrm{pH} 4.6$ after acetic acid addition. These results are not surprising because calcium and phosphate, which contribute to the buffer capacity of milk, are removed from milk during UF and MF. As a result, the buffering capacity of the UF or MF retentate sample per gram of protein is lower than the buffering capacity of milk per gram of protein.

Minimal and nonsignificant $(P>0.05)$ differences in NCN content were observed between the $\mathrm{pH} 4.6$ and 4.8 treatments after sodium acetate addition at each pH after acetic acid addition. Moir (1931) also reported that sodium acetate addition resulted in small differences (1-2\%) in NCN as compared with using acetic acid alone.

The filtrate SDS-PAGE protein profiles are presented in Figure 1. Additionally, the intensity of the caseins (peak 3,4 , and 5) relative to the total intensity in each lane is shown in each figure. The casein fraction present in the filtrate of the $\mathrm{pH} 4.6$ treatments (after acetic acid addition) was significantly $(P<0.05)$ lower than the $\mathrm{pH} 4.0$ treatments (after acetic acid addition). These results corresponded to the NCN results. However, no significant $(P>0.05)$ difference was found between the standard method and the $\mathrm{pH} 4.6$ treatments (after acetic acid addition) in terms of casein fraction in the SDS-PAGE profile. This is somewhat surprising because the NCN content (by the Kjeldahl method) of the $\mathrm{pH} 4.6$ treatments (after acetic acid addition) was lower than that of the standard method. The lack of observed difference in electrophoresis may have been caused by limitations of the quantitative systems. In a summary report, Ribadeau-Dumas and Grappin (1989) indicated a scan of a gel by densitometer facilitated quantitative analysis of each protein fraction relative to the total protein. However, a systematic study by Fishbein (1972) indicated a 10 to $15 \%$ deviation in densitometry with Coomassie Blue in acrylamide gel slabs. Factors such as the migration distance, homogeneity, and concentration of protein could cause the deviation in quantification. This current study used a scanned gel image and ImageQuant TL software (Amersham Biosciences); the accuracy and precision of this quantitative system has not been investigated.

The difference may also be because the 2 methods measure different things. The Kjeldahl method determined the total net protein content in the filtrate by $\mathrm{N}$ analysis, whereas the SDS-PAGE method measures the intensity of the casein fraction relative to the total intensity in the filtrate. Kjeldahl results are more inclusive than the gel electrophoresis results and include blood serum albumin, immunoglobulin, $\beta$-lactoglobulin, $\alpha$-lactalbumin, and proteose peptones in the filtrate (Shahani and Sommer, 1951; Aschaffenburg, 1959; Farah, 1979). However, proteose peptones are not visualized in PAGE (Smith, 1968; Basch et al., 1985, 1989) and were not included in the SDS-PAGE quantitative results in this study.

Figure 1 also shows the presence of casein proteins in all of the filtrate samples, indicating that caseins did not precipitate completely even at $\mathrm{pH}$ 4.6. The results are not surprising because the term casein is difficult to define (Jenness, 1970). The American Dairy Science Association (ADSA) committee (Walstra and Jenness, 1984) defined casein as the group of proteins precipitated from raw skim milk by acidification to $\mathrm{pH} 4.6$ at $20^{\circ} \mathrm{C}$. The committee made the decision out of the consideration of common usage and ease of definition on an operational basis. According to the ADSA definition, all intact caseins and the $\gamma$-casein fractions of $\beta$-casein precipitate, but the proteose peptone compounds, most of which are $\beta$-casein fragments, do not. Additionally, the $\mathrm{pI}$ of the whole casein micelle is 4.6 , but the $\mathrm{pI}$ of individual casein components differs. The pI of $\alpha$-casein, 


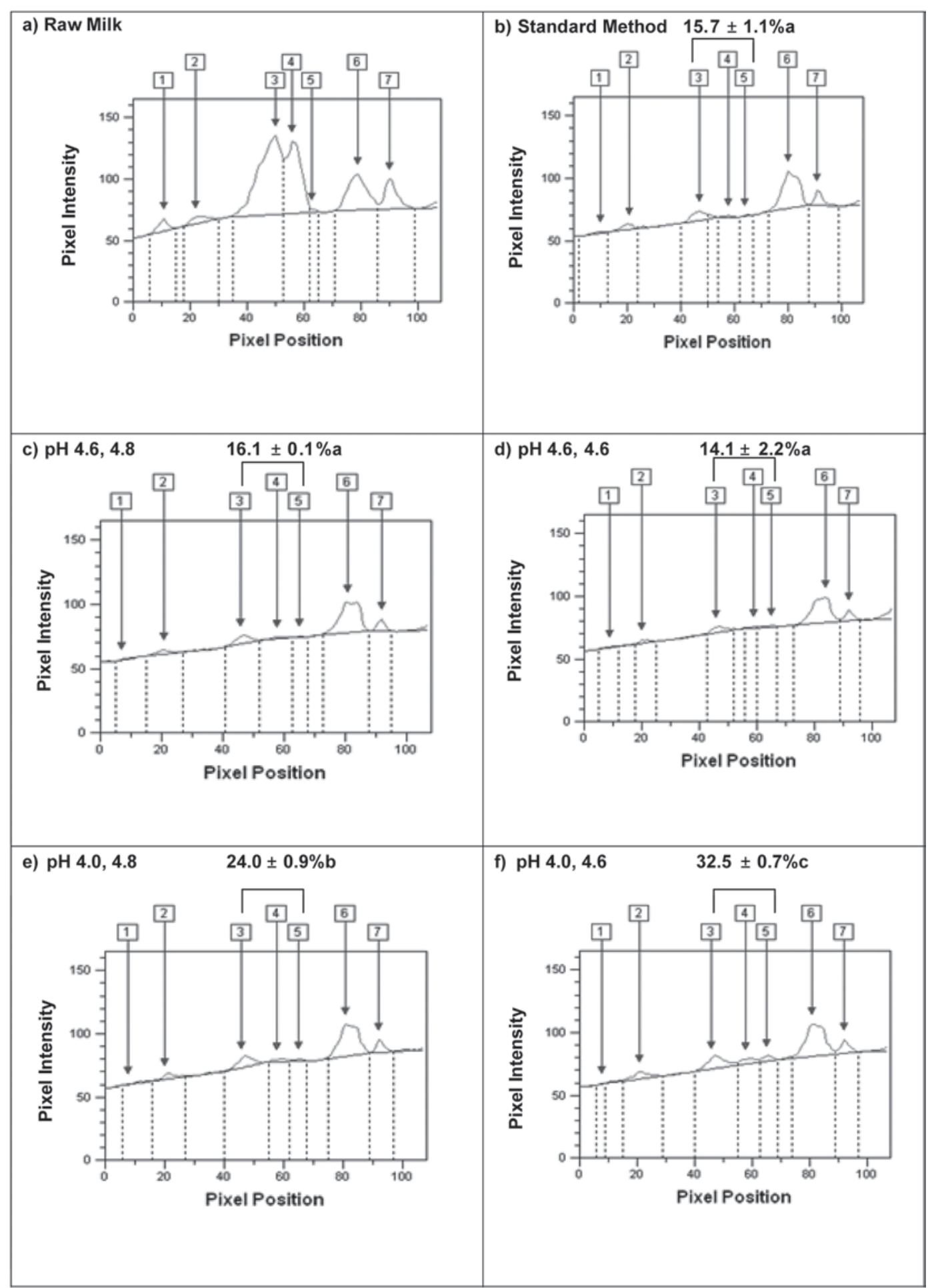

Figure 1. The ImageQuant TL (version 7.0; Amersham Biosciences, Piscataway, NJ) image scan of SDS-PAGE protein profiles of filtrates. Numbers in boxes refer to the following: 1) lactoferrin + blood serum albumin, 2) immunoglobulin, 3) $\alpha_{\mathrm{s} 2}+\alpha_{\mathrm{s} 1}$ caseins, 4) $\beta$-casein $+\kappa$-casein, 5) $\gamma$-casein, 6) $\beta$-lactoglobulin, and 7) $\alpha$-lactalbumin. The percent (average $\pm \mathrm{SE}, \mathrm{n}=2$ ) listed on top of each sample image is the sum of the casein protein fractions (peaks 3,4 , and 5) in pixel intensity. Letters a to c indicate statistical significance among the treatments. 
Table 3. Comparison of 2 methods used to measure noncasein nitrogen (NCN) content in UF and microfiltration $(\mathrm{MF})$ retentate samples

\begin{tabular}{lccc}
\hline Sample & $\begin{array}{c}\text { Standard } \\
\text { method }^{1}(\mathrm{n}=3)\end{array}$ & $\begin{array}{c}\text { Modified } \\
\text { method }^{2}(\mathrm{n}=3)\end{array}$ & $\begin{array}{c}\text { Difference } \\
\text { between the } \\
2 \text { methods }\end{array}$ \\
\hline UF 5\% & $0.99 \pm 0.03^{\mathrm{a}}$ & $0.94 \pm 0.01^{\mathrm{a}}$ & 0.04 \\
UF 6\% (source 1) & $1.22 \pm 0.01^{\mathrm{a}}$ & $1.17 \pm 0.01^{\mathrm{b}}$ & 0.05 \\
UF 8\% & $0.96 \pm 0.02^{\mathrm{b}}$ & 0.24 \\
UF 8\% (source 2) & $1.20 \pm 0.05^{\mathrm{a}}$ & $1.37 \pm 0.02^{\mathrm{b}}$ & 0.09 \\
UF 10\% & $1.46 \pm 0.01^{\mathrm{a}}$ & $1.68 \pm 0.02^{\mathrm{b}}$ & 0.10 \\
UF 14\% & $1.78 \pm 0.03^{\mathrm{a}}$ & $2.44 \pm 0.01^{\mathrm{b}}$ & 0.10 \\
MF 6.9\% & $2.69 \pm 0.07^{\mathrm{a}}$ & $0.52 \pm 0.02^{\mathrm{b}}$ & 0.06 \\
MF 8.6\% & $0.62 \pm 0.03^{\mathrm{a}}$ & $0.71 \pm 0.01^{\mathrm{b}}$ & 0.13 \\
MF 10.6\% & $0.77 \pm 0.03^{\mathrm{a}}$ & $1.16 \pm 0.02^{\mathrm{b}}$ & 0.03 \\
MF 11.3\% & $1.29 \pm 0.03^{\mathrm{a}}$ & $0.46 \pm 0.02^{\mathrm{a}}$ & 0.06 \\
MF 12.4\% & $0.49 \pm 0.02^{\mathrm{a}}$ & $1.48 \pm 0.01^{\mathrm{b}}$ & 0.09 \\
MF 15.5\% & $1.54 \pm 0.04^{\mathrm{a}}$ & $0.71 \pm 0.02^{\mathrm{a}}$ & 0.10 \\
MF/UF 15.1\% & $0.80 \pm 0.04^{\mathrm{a}}$ & $1.11 \pm 0.01^{\mathrm{b}}$ & \\
Average SE & $1.21 \pm 0.01^{\mathrm{a}}$ & 0.015 &
\end{tabular}

${ }^{\mathrm{a}, \mathrm{b}}$ Different letters within the same row indicate a significant difference among treatment means $(P<0.05)$. Values are means \pm standard error.

${ }^{1}$ Sample preparation using the standard method followed the procedures of Hooi et al. (2004), except that a sample size of $3.25 \mathrm{~g}$ of retentate and $10 \mathrm{~mL}$ of $1 \%$ acetic acid were used.

${ }^{2}$ The modified method used a 50-mL centrifuge tube, and the weight of each sample was correspondingly half of the sample size used in the standard method.

$\beta$-casein, and $\gamma$-casein, in terms of minimum solubility, are $4.7,4.9$, and 5.8 respectively (Jenness and Patton, 1959).

Even though we could not completely remove caseins from the filtrate, the modified method gave significantly $(P<0.05)$ lower NCN values than did the standard method when the $\mathrm{pH}$ after acetic acid addition was 4.6. Based on the results, we recommend utilizing the modified method and monitoring the $\mathrm{pH}$ after acetic acid addition to ensure that a value of 4.6 is obtained.

\section{Verification of the Modified New Method}

Table 2 shows the adjusted sample weight, the actual $\mathrm{pH}$ values for the various samples, as well as the amount of acetic acid and sodium acetate added to each sample. Because the sample size was adjusted to the protein equivalent of $10 \mathrm{~mL}$ of typical bovine milk used in the standard method, the amount of $1 \%$ acetic acid was constant and not adjusted in the standard method. The $\mathrm{pH}$ values after acetic acid addition using the standard method and a $100-\mathrm{mL}$ volumetric flask were not measured during sample preparation. The modified method used a 50-mL centrifuge tube, and the weight of each sample was correspondingly half of the sample size used in the standard method. In the modified method, the amount of $1 \%$ acetic acid added to reach $\mathrm{pH} 4.6$ was adjusted for each sample and ranged from 2.45 to $2.9 \mathrm{~mL}$ (Table 2). Overall, the amount of acetic acid in the modified method was approximately one-quarter of the addition quantity $(10 \mathrm{~mL})$ of $1 \%$ acetic acid in the standard method. Additionally, the amount $(0.15-0.2 \mathrm{~mL})$ of $1 \mathrm{~N}$ sodium acetate added to increase final filtrate $\mathrm{pH}$ value to 4.8 in the modified method was only 15 to $20 \%$ of that amount $(1 \mathrm{~mL})$ used in the standard method, which led to a final $\mathrm{pH}$ of about 4.7. Based on these observations, we can assume that the $\mathrm{pH}$ values after acetic acid addition using the standard method were lower than 4.6.

The filtrates were analyzed by the Kjeldahl method for NCN analysis and their results are presented in Table 3 . Ten of the thirteen samples had a significant $(P$ $<0.05$ ) lower NCN content with the modified method as compared with the standard method. The 3 samples with no significant $(P>0.05)$ difference between the 2 methods tended to be low in NCN. The lower NCN content result achieved by the modified method as compared with the standard method in most samples is most likely a result of the presumed lower $\mathrm{pH}$ after acetic acid addition in the standard method.

Additionally, the average standard error for the 13 retentate samples, using the modified method, was half of the average standard error for the standard method (Table 3). The results indicated that the modified method gave more reproducible results as compared with the standard method. Overall, this study demonstrates that the proposed modification in the standard method will improve the accuracy and repeatability of NCN analysis of UF and MF retentate samples. 


\section{CONCLUSIONS}

The use of a 50-mL centrifuge tube in the modified method facilitated the determination of the $\mathrm{pH}$ after addition of acetic acid, which is critical for analysis for UF and MF retentate samples. We determined that the $\mathrm{pH}$ after acetic acid addition played a determining role in casein coagulation and affected NCN results. As the $\mathrm{pH}$ after acetic acid addition was increased from 4.0 to 4.6, the NCN content determined by Kjeldahl analysis significantly decreased. The SDS-PAGE results also indicated that the casein fractions present in the filtrate were significantly decreased when the $\mathrm{pH}$ was increased from 4.0 to 4.6. Based on the results, we recommend using the modified method and monitoring the $\mathrm{pH}$ to ensure that it is at 4.6 after acetic acid addition. The NCN content of $13 \mathrm{MF}$ and UF samples was determined using the standard method and the modified method. The verification study found that modified method gave significantly lower NCN values for most samples relative to the standard method. Consequently, we recommend using the modified method for NCN analysis of MF and UF retentate samples.

\section{ACKNOWLEDGMENTS}

We acknowledge financial support provided by Dairy Management Inc. (Rosemont, IL) as administered by Dairy Research Institute (Chicago, IL).

\section{REFERENCES}

Aschaffenburg, R., and J. Drewry. 1959. New procedure for the routine determination of the various non-casein proteins of milk. Pages 1631-1636 in XV International Dairy Congress, London, UK. Volume 3. Richard Clay and Co., Bungay, Suffolk, UK.

AOAC. 2000. Official Methods of Analysis. 17th ed. AOAC. Association of Official Analytical Chemists, Gaithersburg, MD.

Barbano, D. M., J. M. Lynch, and J. R. Fleming. 1991. Direct and indirect determination of true protein content of milk by Kjeldahl analysis: Collaborative study. J. Assoc. Off. Anal. Chem. $74: 281-288$.

Basch, J. J., F. W. Douglas Jr., L. G. Procino, V. H. Holsinger, and H. M. Farrell Jr. 1985. Quantitation of caseins and whey proteins of processed milks and whey protein concentrates application of gel electrophoresis, and comparison with Harland-Ashworth procedure. J. Dairy Sci. 68:23-31.

Basch, J. J., H. M. Farrell Jr., R. A. Walsh, R. P. Konstance, and T. F. Kumosinski. 1989. Development of a quantitative model for enzyme-catalyzed, time-dependent changes in protein composition of Cheddar cheese during storage. J. Dairy Sci. 72:591-603.

Farah, Z. 1979. Examination of Aschaffenburg and Drewry procedure for determination of non-casein-proteins of milk by discontinuous polyacrylamide electrophoresis. Z. Lebensm. Unters. Forsch. 168:394-396.

Farrell, H. M. Jr., and T. F. Kumosinski. 1988. Modeling of calciuminduced solubility profiles of casein for biotechnology: Influence of primary structure and post-translational modification. J. Ind. Microbiol. 3:61-71.

Fishbein. W. N. 1972. Quantitative densitometry of 1-50 $\mu \mathrm{g}$ protein in acrylamide gel slabs with Coomassie Blue. Anal. Biochem. 46:388-401.

Fox, P. F., and A. Brodkorb. 2008. The casein micelle: Historical aspects, current concepts and significance. Int. Dairy J. 18:677684.

Hooi, R., D. M. Barbano, R. L. Bradley, D. Buddle, M. Bulthaus, M. Chettiar, J. Lynch, and R. Reddy. 2004. Chemical and physical methods. Pages 363-532 in Standard Methods for the Examination of Dairy Products. 17th ed. H. M. Wehr and J. F. Frank, ed. American Public Health Association, Washington, DC.

Jenness, R. 1970. Protein composition of milk. Pages 17-43 in Milk Protein Chemistry and Molecular Biology. Vol. I. H. A. McKenzie, ed. Academic Press, New York, NY and London, UK.

Jenness, R., and S. Patton. 1959. Principles of Dairy Chemistry. John Wiley \& Sons Inc, New York, NY.

Lynch, J. M., D. M. Barbano, and J. R. Fleming. 1998. Indirect and direct determination of the casein content of milk by Kjeldahl nitrogen analysis: Collaborative study. J. AOAC Int. 81:763-774.

McMahon, D. J., and B. S. Oommen. 2008. Supramolecular structure of the casein micelle. J. Dairy Sci. 91:1709-1721.

Moir, G. M. 1931. The determination of the milk proteins. III. Proposed modified method for casein. Analyst (Lond.) 56:147-149.

Mora-Gutierrez, A., H. M. Farrell Jr., J. J. Basch, and C. Kumosinski. 1993. Modeling calcium-induced solubility in caprine milk caseins using a thermodynamic linkage approach. J. Dairy Sci. 76:36983710 .

Nelson, B. K., and D. M. Barbano. 2005. A microfiltration process to maximize removal of serum proteins from skim milk before cheese making. J. Dairy Sci. 88:1891-1900.

Philippe, M., F. Gaucheron, Y. Le Graet, F. Michel, and A. Garem. 2003. Physicochemical characterization of calcium-supplemented skim milk. Lait 83:45-59.

Ribadeau-Dumas, B., and R. Grappin. 1989. Milk protein analysis. Lait 69:357-416.

Rowland, S. J. 1938. The precipitation of the proteins in milk. I. Casein. II. Total proteins. III. Globulin. IV. Albumin and proteosepeptone J. Dairy Res. 9:30-41.

Shahani, K. M., and H. H. Sommer. 1951. The protein and non-protein nitrogen fractions in milk. I. Methods of analysis. J. Dairy Sci. 34:1003-1009.

Smith, I. 1968. Chromatographic and Electrophoretic techniques. Volume II. 2nd ed. Interscience Publishers, Inc., New York, NY, William Heinemann, Ltd., London, UK.

von Hippel, P. H., and D. F. Waugh. 1955. Casein: Monomers and polymers. J. Am. Chem. Soc. 77:4311-4319.

Walstra, P., and R. Jenness. 1984. Dairy Chemistry and Physics. John Wiley \& Sons, New York, NY. 